EDITORIAL ESPECIAL

SPECIAL EDITORIAL

\section{Pandemia de Influenza: Seminário Internacional}

Influenza

Pandemic: International Seminar

Maria Rita Donalísio

Membro da Comissão de Epidemiologia da ABRASCO e da FCM-Unicamp

Departamento de Medicina Preventiva e Social da

Faculdade de Ciências Médicas da Unicamp

Caixa Postal 6111

Campinas - SP

13083-970

donalisi@fcm.unicamp.br
Grande parte das enfermidades humanas origina-se de reservatórios animais; estima-se que $75 \%$ das doenças emergentes são zoonóticas. A existência de múltiplos reservatórios do vírus da influenza na natureza favorece recombinações de vírus que circulam em humanos e animais ou mutações do genoma viral, aumentando a possibilidade de emergência de novos subtipos, aos quais a população humana é susceptível.

As epidemias de influenza, bem como de outras doenças respondem a determinantes sociais, culturais, ecológicos que favorecem a disseminação de novas cepas e influenciam na dinâmica de transmissão no espaço e no tempo. No século XX ocorreram 3 grandes pandemias de influenza: a Gripe Espanhola em 1918-19, a Gripe Asiática em 1957-58 a Gripe de Hong Kong em 1968-69, em contextos históricos e tecnológicos diferentes.

Em 1997 na Ásia, foi registrada a transmissão de aves para humanos de um vírus de alta patogenicidade, influenza A H5N1, colocando o mundo em alerta. A partir de 2003, em um contexto econômico e cultural de convivência próxima com aves e suínos, têm ocorrido surtos de influenza na China, Vietnam, Coréia e Tailândia com expressão clínica severa e alta letalidade. Foi identificado o vírus A H5N1, já com evidente mudança em sua caracterização antigênica, comparada com a cepa de 1997, sugerindo a ocorrência de mutações adaptativas nesta cepa.

A história de antigas pandemias de influenza deixou lições, porém hoje nenhum modelo pode predizer a magnitude, a gravidade e mesmo a etiologia precisa de uma próxima pandemia. A população urbana cresceu, há maior contingente de doentes crônicos e idosos, houve aumento da pobreza e iniqüidade em algumas regiões, além da maior rapidez de transportes facilitando a circulação de patógenos ao redor do mundo. Ao mesmo tempo há possibilidade de síntese de vacina em larga escala, uso de antivirais profiláticos e terapêuticos, além de melhor abordagem clínica de suporte aos pacientes com quadros graves.
Most human diseases originate from animals. It is estimated that $75 \%$ of emerging diseases are zoonotic. The existence of multiple reservoirs of the influenza virus in nature favors the recombination of human and animal viruses or mutations of the viral genome, increasing the likelihood of the emergence of new subtypes, to which the human population is susceptible.

Influenza epidemics, as well as other diseases, respond to social, cultural and ecological determinants that favor the dissemination of new strains and influence transmission dynamics in space and time. In the $20^{\text {th }}$ century, there were 3 major influenza pandemics: the Spanish Flu in 1918-19, the Asian Influenza in 1957-58, the Hong Kong Influenza in 1968-69, all in different historical and technological scenarios.

In 1997 in Asia, a highly pathogenic virus, influenza A H5N1, was transmitted from birds to humans setting the world on guard. After 2003, due to an economic and cultural situation of contact between birds and swine, there have been outbreaks of influenza in China, Vietnam, Korea, and Thailand, with severe clinical expression and high lethality. When virus A H5N1 was identified, there already were clear changes in its antigenic features, if compared to the 1997 strain, suggesting the occurrence of adaptive mutations in this strain.

Although the history of past influenza pandemics has taught us a few lessons, today no model can predict the exact magnitude, severity, and etiology of the next pandemic. The urban population has grown, there are a larger number of chronic and elderly patients, and there has been an increase in poverty and inequality in some regions, in addition to faster transportation that facilitates the circulation of pathogens around the world. At the same time, it is possible to produce vaccines in a large scale, to use prophylactic and therapeutic antiviral drugs, in addition to an improved clinical approach to support patients with severe diseases.

In face of the uncertainty, we are left with the challenge of getting ready for the 
Diante da incerteza, resta o desafio de preparar-se para o inesperado, estudando possíveis cenários.

Em vários fóruns internacionais e nacionais, entre eles o Seminário Internacional sobre a Pandemia de Influenza, em novembro no Rio de Janeiro tem-se discutido medidas possíveis, como a preparação de instituições para a produção de uma vacina apropriada no Brasil, um estoque nacional estratégico de antivirais, critérios e prioridades, $\mathrm{o}$ provável impacto em internações e mortes, medidas para proteção individual e coletiva na comunidade e em serviços de saúde, vigilância epidemiológica e virológica. Há consenso sobre: trabalhar em rede e com parcerias, priorizar o enfoque metropolitano, controlar a doença no foco, reforçar a vigilância virológica e epidemiológica em humanos e animais, monitorando mutações e circulação de vírus, investir em recursos terapêuticos e laboratoriais. O Ministério da Saúde e Estados têm proposto planos de contingência flexíveis que possam responder e adaptar-se a inesperadas versões da doença e da transmissão.

São as epidemias reeditadas, novas velhas e velhas novas que exigem dos técnicos da área, flexibilidade e criatividade, solidariedade e transparência para responder ao inesperado. unexpected by studying possible scenarios.

In many national and international forums, including the International Seminar on the Influenza Pandemic, held in November, in Rio de Janeiro, possible measures were discussed, like the readiness of institutions for the production of an appropriate vaccine in Brazil, a strategic national inventory of antiviral agents, criteria and priorities, the probable impact on hospitalizations and deaths, measures for individual and collective protection in the community and healthcare services, and epidemiological surveillance, and other issues. There is a consensus as to the need of working as a network and in partnerships, to prioritize the metropolitan approach, control the disease on its focus, reinforce virological and epidemiological surveillance in humans and animals, monitoring mutations and circulation of viruses, invest in therapeutic and laboratory resources. The Ministry of Health and the States have presented flexible contingency plans that may respond and adapt to unexpected versions of the diseases and transmission.

These are re-edited epidemics, old new diseases and new old diseases, which require flexibility and creativity, solidarity, and transparence from technicians to respond to the unexpected. 